\title{
Usulan Perbaikan Tata Letak Fasilitas Pabrik Tahu dengan Metode Systematic Layout Planning
}

\author{
Adik Ahmad Unggul Nugeroho \\ Teknik Industri, Universitas Indraprasta PGRI \\ *Corresponding author: adikahmadunggulnugeroho@gmail.com
}

\section{ARTICLE INFORMATION}

Received: 20 Agustus 2021

Revised: 22 Agustus 2021

Accepted: 30 Agustus 2021

Available online: 25 September 2021

\section{KEYWORDS}

Re-Layout

Systematic Layout Planning

Usaha Kecil Mikro

Produk Tahu

\section{A B S T R A K}

\begin{abstract}
Tingkat persaingan yang tinggi dalam industri ini akhirnya mengharuskan untuk menentukan strategistrategi yang tepat agar dapat menjaga produktivitas sehingga keuntungan yang didapatkan pun dapat terus ditingkatkan. UKM BM adalah salah satu usaha yang bergerak di bidang pengolahan kedelai yaitu memproduksi tahu. Keadaan lantai produksi di UKM BM saat ini masih belum tersusun dengan tepat. Hal ini dapat dilihat pada dari bentuk pola aliran bahan yang ada. Pola aliran yang tidak teratur membuat timbulnya back-tracking dari perpindahan aliran bahan didalam proses produksi yang berdampak pada ongkos material handling. Oleh karena itu perlu adanya suatu pertimbangan bagaimana membuat atau mengubah tata letak fasilitas yang lebih efektif dan efisien, Tujuan dari penelitian ini adalah merekomendasikan suatu rancangan tata letak fasilitas produksi tahu yang baru dengan optimalisasi yang diperoleh dari segi jarak tempuh aliran bahan. Perancangan tata letak menggunakan metode Systematic Layout Planning (SLP) dibuat untuk menyelesaikan permasalahan yang menyangkut berbagai macam permasalahan aliran material produski, transpotasi, pergudangan, supporting, perakitan dan aktivitas kantor adapun hasil dari penelitian ini adalah Jarak material handling pada layout awal yaitu 537.5 meter/ produksi dengan ongkos material handling Rp. 60.000/ produksi. hasil rancangan perbaikan pada layout usulan menunjukan jarak material handling lebih pendek yaitu 424.5 meter/ produksi dengan ongkos material handling Rp. 47.374/ produksi.
\end{abstract}

\section{PENDAHULUAN}

Tingkat persaingan yang tinggi dalam industri ini akhirnya mengharuskan untuk menentukan strategistrategi yang tepat agar dapat menjaga produktivitas sehingga keuntungan yang didapatkan pun dapat terus ditingkatkan. Salah satu cara atau strategi untuk mewujudkan tujuan tersebut adalah dengan mengatur tata letak fasilitas [1]. Tata letak fasilitas memiliki dampak yang cukup significant terhadap performansi perusahaan seperti ongkos material handling, work in process inventory, lead time, produktivitas dan serta performansi pendistribusian [2]. Sistem material handling yang kurang sistematis menjadi masalah yang cukup besar dan menggangu kelancaran proses produksi sehingga mempengaruhi sistem secara keseluruhan [3].

UKM BM adalah salah satu usaha yang bergerak di bidang pengolahan kedelai yaitu memproduksi tahu. Keadaan lantai produksi di UKM BM saat ini masih belum tersusun dengan tepat. Hal ini dapat dilihat pada dari bentuk pola aliran bahan yang ada. Pola aliran yang tidak teratur membuat timbulnya back-tracking dari perpindahan aliran bahan didalam proses produksi yang berdampak pada ongkos material handling. Oleh karena https://doi.org/10.30998/joti.v3i2.10452 itu perlu adanya suatu pertimbangan bagaimana membuat atau mengubah tata letak fasilitas yang lebih efektif dan efisien

Tujuan dari penelitian ini adalah merekomendasikan suatu rancangan tata letak fasilitas produksi tahu yang baru dengan optimalisasi yang diperoleh dari segi jarak tempuh aliran bahan.

\section{METHOD}

Langkah awal yang harus dilakukan sebelum melakukan penelitian adalah melakukan studi pendahuluan. Studi pendahuluan dilakukan ke industri rumahan pembuatan tahu UKM BM yang berada di jalan Merpati Raya, Harapan Jaya kota Bekasi yang menjadi objek penelitian. Langkah ini dilakukan untuk mengetahui permasalahan yang ada di pabrik pembuatan tahu ini.

Langkah selanjutnya yang dilakukan adalah pengumpulan data awal kondisi layout pabrik sesuai dengan pendekatan Systematic Layout Planning (SLP). Perancangan tata letak menggunakan metode Systematic Layout Planning (SLP) dibuat untuk menyelesaikan permasalahan yang menyangkut berbagai macam permasalahan aliran material produski, transpotasi, 
pergudangan, supporting, perakitan dan aktivitas kantor [4].

Metode Systematic Layout Planning jika dilakukan dengan baik dan benar akan menghasilkan suatu hasil yang baik. Adapun tahapan dalam metode ini [5][6][7]:

1. Langkah 1 Aliran Material

Analisis aliran material merupakan analisis pengukuran kuantitatif untuk setiap gerakan perpindahan material di antara departemendepartemen atau aktivitas-aktivitas operasional. Dalam menganalisis aliran material ini sering digunakan peta atau diagram seperti peta aliran proses, diagram alir, peta proses produk banyak, from to chart, peta hubungan aktivitas dan peta perakitan.

2. Langkah 2 Activity Relationship Chart (ARC)

Activity Relationship Chart (ARC) menampilkan keterkaitan antar area yang ada dalam menunjang aktivitas selama produk dibuat. Dengan ARC dapat ditentukan tingkat kedekatan antar proses satu dengan lainnya

3. Langkah 3 Activity Relationship Diagram (ARD)

Activity Relationship Diagram (ARD) pendekatan Muther yaitu penggambaran ARD dengan hubungan garis yang menunjukkan besarnya tingkat hubungan antara kegiatan yang satu dengan kegiatan yang lain. Adapun dasar ARD adalah dari ARC

4. Langkah 4 dan 5 penyesuaian

Terdapat 3 (tiga) hal yang dapat dijadikan dasar untuk menentukan luas ruang yang dibutuhkan, yaitu tingkat produksi (production rate), peralatan yang dibutuhkan untuk proses produksi dan karyawan yang diperlukan dan Dalam beberapa kasus tertentu, khususnya untuk problem relayout seringkali layout yang didesain harus disesuaikan dengan luas bangunan pabrik yang tersedia. Demikian juga untuk kasus yang lain dimana biaya serba terbatas, maka luas area yang bisa disediakan pun akansangat terbatas sekali.

5. Langkah 6 Space Relationship Diagram (SRD)

Dalam proses pembuatan Space Relationship Diagram ini yang perlu diperhatikan adalah mengevaluasi luas ruang yang dibutuhkan untuk semua aktivitas perusahaan dan ruang yang tersedia.

6. Langkah 7 dan 8 Modifying Consideration dan Practical Limitation

Disini pertimbangan-pertimbangan praktis dibuat untuk modifikasi layout

7. Langkah 9 rancangan Alternatif Layout

Develop Layout Alternatives dibuat berdasarkan Space Relationship Diagram dengan mempertimbangkan modifikasi dan berdasarkan pertimbangan praktis.

8. Langkah 10 Decision alternative, implimentasi, dan evaluasi

Ada beberapa kriteria atau teknik-teknik yang dapat digunakan untuk mengevaluasi alternatif tata letak,

66 Adik Ahmad unggul Nugeroho yaitu perbandingan untung rugi, peringkat, analisis faktor dan perbandingan biaya

\section{HASIL DAN PEMBAHASAN}

\section{Tata Letak Awal}

UKM BM bediri diatas lahan seluas 7 Meter x 11 Meter. Tata letak awal lantai produksi di UKM BM dapat dilihat pada gambar berikut ini:

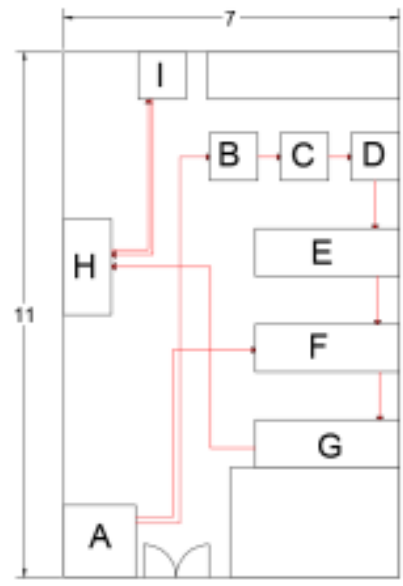

Gambar 1. Tata Letak Awal UKM BM

Keterangan:

$$
\begin{array}{ll}
\mathrm{A} & =\text { Raw Material } \\
\mathrm{B} & =\text { Pencucian Kedelai } \\
\mathrm{C} & =\text { Proses Perendaman Kedelai } \\
\mathrm{D} & =\text { Proses Pengilingan } \\
\mathrm{E} & =\text { Proses Perebusan Sari Kedelai } \\
\mathrm{F} & =\text { Proses Penyaringan } \\
\mathrm{G} & =\text { Proses Pencetakan } \\
\mathrm{H} & =\text { Proses Pengorengan } \\
\mathrm{I} & =\text { Storage }
\end{array}
$$

\section{Jarak dan Biaya Perpindahan Bahan Baku Tata Letak Awal}

Biaya perpindahan bahan di pengaruhi oleh ongkos material handling per meter, jarak antar stasiun kerja yang berhubungan, dan frekuensi perpindahan yang terjadi.

Pada tata letak awal dapat diketahui bahwa hasil dari jarak pemindahan bahan baku dan aktivitas produksi didapat dengan cara membadingkan berapa banyak jumlah unit yang dapat di pindahkan seperti pada Tabel 1 berikut ini:

Tabel 1. Total Jarak Antar Proses Produksi Tahu

\begin{tabular}{ccccc}
\hline From & To & $\begin{array}{c}\text { Jarak } \\
\text { (Meter) }\end{array}$ & Frekuensi & $\begin{array}{c}\text { Total Jarak } \\
\text { (Meter) }\end{array}$ \\
\hline A & B & 6.5 & 6 & 39 \\
B & C & 1.5 & 10 & 15 \\
C & D & 1.5 & 26 & 39 \\
D & E & 1.5 & 16 & 24 \\
E & F & 1.5 & 16 & 24 \\
A & F & 3.5 & 4 & 14 \\
F & G & 1.5 & 25 & 37.5 \\
G & I & 4.5 & 30 & 135 \\
I & H & 3.5 & 30 & 105 \\
H & I & 3.5 & 30 & 105 \\
& & TOTAL & & $\mathbf{5 3 7 . 5}$ \\
\hline
\end{tabular}


Ongkos material handling berdasarkan tenaga manusia (Operator), berikut ini adalah perhitungan ongkos material handling pada UKM BM yang dihitung berdasarkan jarak tempuh atau ongkos per meter adalah sebagai berikut:

Upah operator $=60.000 \mathrm{rupiah} / \mathrm{har}$

Waktu kerja operator $=7$ jam/hari

$$
=\frac{60.000 \mathrm{rupiah} / \mathrm{hari}}{7 \mathrm{jam} / \mathrm{hari}}=8.571,42 \mathrm{rupiah} / \mathrm{jam}
$$

Total Ongkos Material Handling Operator

$$
\text { Total }=\frac{8.571,42 \mathrm{rupiah} / \mathrm{jam}}{76,78 \mathrm{~meter} / \mathrm{jam}}=111,6 \mathrm{rupiah} / \mathrm{meter}
$$

Tabel 2. Total OMH Tata Letak awal

\begin{tabular}{ccccccc}
\hline From & To & $\begin{array}{c}\text { Material } \\
\text { Handling }\end{array}$ & $\begin{array}{c}\text { Jarak } \\
(\text { Meter) }\end{array}$ & $\begin{array}{c}\text { OMH } \\
(\mathrm{Rp})\end{array}$ & Frekuensi & $\begin{array}{c}\text { Total OMH } \\
\text { (Rp) }\end{array}$ \\
\hline A & B & Manusia & 6.5 & 111.6 & 6 & 4352,4 \\
B & C & Manusia & 1.5 & 111.6 & 10 & 1674 \\
C & D & Manusia & 1.5 & 111.6 & 26 & 4352,4 \\
D & E & Manusia & 1.5 & 111.6 & 16 & 2678,4 \\
E & F & Manusia & 1.5 & 111.6 & 16 & 2678,4 \\
A & F & Manusia & 3.5 & 111.6 & 4 & 1562,4 \\
F & G & Manusia & 1.5 & 111.6 & 25 & 4185 \\
G & I & Manusia & 4.5 & 111.6 & 30 & 15066 \\
I & H & Manusia & 3.5 & 111.6 & 30 & 11718 \\
H & I & Manusia & 3.5 & 111.6 & 30 & 11718 \\
& \multicolumn{7}{c}{ TOTAL } & & & 60000 \\
\hline
\end{tabular}

Dari tabel diatas menunjukan bagwa total biaya yang keluar untuk Material Handling dalam satu hari Rp. 60.000,-.

\section{Systematic Layout Planning}

Tahap awal untuk berbaikan tata letak fasilitas yaitu membuat activity relationship chart (ARC). ARC merupakan grafik hubungan aktifitas antar area. ARC berguna untuk mengetaui tingkat kepentingan kedekatan suatu area ke area lainnya. Dari ARC ini didapatkan tabel kerja bantu dan tabel skala prioritas. Berikut ini merupakan Activity Relationship Chart (ARC) prosuksi tahu:

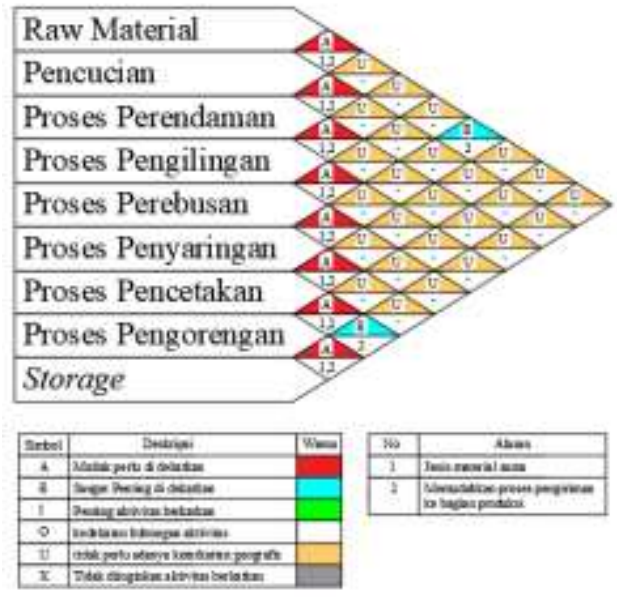

Gambar 2. Activity Relationship Chart (ARC)
Setelah membuat ARC selanjutnya dilakukan pembuatan Resume From To Chart, Resume Outflow dan Skala Prioritas dapat lihat pada tabel dibawah ini:

Tabel 3. Resume FTC Proses Produksi Tahu

\begin{tabular}{ccccccccccc}
\hline & $\mathrm{A}$ & $\mathrm{B}$ & $\mathrm{C}$ & $\mathrm{D}$ & $\mathrm{E}$ & $\mathrm{F}$ & $\mathrm{G}$ & $\mathrm{H}$ & $\mathrm{I}$ & $\sum$ \\
\hline $\mathrm{A}$ & $\mathrm{xx}$ & 2 & & & & 1 & & & & 3 \\
$\mathrm{~B}$ & & $\mathrm{xx}$ & 2 & & & & & & & 2 \\
$\mathrm{C}$ & & & $\mathrm{xx}$ & 2 & & & & & & 2 \\
$\mathrm{D}$ & & & & $\mathrm{Xx}$ & 2 & & & & & 2 \\
$\mathrm{E}$ & & & & & $\mathrm{xx}$ & 1 & & & & 1 \\
$\mathrm{~F}$ & & & & & & $\mathrm{xx}$ & 1 & & & 1 \\
$\mathrm{G}$ & & & & & & & $\mathrm{xx}$ & & 1 & 1 \\
$\mathrm{H}$ & & & & & & & & $\mathrm{xx}$ & 1 & 1 \\
$\mathrm{I}$ & & & & & & & & 1 & $\mathrm{xx}$ & 1 \\
$\sum$ & & 2 & 2 & 2 & 2 & 2 & 1 & 1 & 2 & 14 \\
\hline
\end{tabular}

Tabel 4. Resume Outflow Proses Produksi Tahu

\begin{tabular}{ccccccccccc}
\hline & $\mathrm{A}$ & $\mathrm{B}$ & $\mathrm{C}$ & $\mathrm{D}$ & $\mathrm{E}$ & $\mathrm{F}$ & $\mathrm{G}$ & $\mathrm{H}$ & $\mathrm{I}$ & $\sum$ \\
\hline $\mathrm{A}$ & $\mathrm{xx}$ & 0.5 & & & & 0.5 & & & & 1 \\
$\mathrm{~B}$ & & $\mathrm{xx}$ & 1 & & & & & & & 1 \\
$\mathrm{C}$ & & & $\mathrm{xx}$ & 1 & & & & & & 1 \\
$\mathrm{D}$ & & & & $\mathrm{Xx}$ & 1 & & & & & 1 \\
$\mathrm{E}$ & & & & & $\mathrm{xx}$ & 1 & & & & 1 \\
$\mathrm{~F}$ & & & & & & $\mathrm{xx}$ & 1 & & & 1 \\
$\mathrm{G}$ & & & & & & & $\mathrm{xx}$ & & 1 & 1 \\
$\mathrm{H}$ & & & & & & & & $\mathrm{xx}$ & 1 & 1 \\
$\mathrm{I}$ & & & & & & & & 1 & $\mathrm{xx}$ & 1 \\
$\sum$ & & 0.5 & 1 & 1 & 1 & 1.5 & 1 & 1 & 2 & 9 \\
\hline
\end{tabular}

Berdasarkan Tabel 3 dan 4 dapat dibuat tabel sakala prioritas kedekatan antar mesin, berikut ini adalah tabel skala prioritas kedekatan antar mesin dapat dilihat pada Tabel 5 sebagai berikut.

Tabel 5. Skala Prioritas

\begin{tabular}{ccccc}
\hline & \multicolumn{4}{c}{ Skala Prioritas } \\
From & & 1 & & \\
B & Bobot & Proses & Bobot & Proses \\
\hline B & 0,5 & B & 0,5 & F \\
C & 1 & C & & \\
D & 1 & D & & \\
E & 1 & E & & \\
F & 1 & F & & \\
G & 1 & G & & \\
H & 1 & H & & \\
I & 1 & I & & \\
\hline
\end{tabular}

Tahap selanjutnya adalah menentukan Allocation Relationship Diagram (ARD) atau diagram keterkaitan kegiatan. ARD dibuat berdasarkan tingkat prioritas kedekatan sehingga diharapkan ongkos handling minimum. Inputan dari Allocation Relationship Diagram adalah tabel skala prioritas, jadi yang menempati prioritas pertama pada pada tabel skala prioritas harus di dekatkan letaknya lalu diikuti priortas berikutnya. Usulan yang dibuat yaitu dapat dilihat pada gambar berikut ini: 


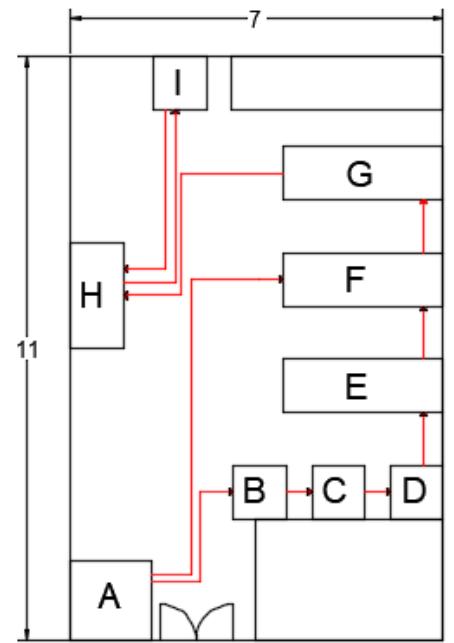

Gambar 3. ARD Usulan

\section{Jarak dan Biaya Perpindahan Bahan Baku Tata Letak Usulan}

Langkah selanjutnya adalah menghitung jarak dan biaya perpindahan bahan baku yang dapat dilihat pada tabel 6 berikut ini:

Tabel 6. Total Jarak Antar Proses Tata Letak Usulan Produksi

\begin{tabular}{ccccc}
\multicolumn{5}{c}{ Tahu } \\
\hline From & To & $\begin{array}{c}\text { Jarak } \\
\text { (Meter) }\end{array}$ & Frekuensi & $\begin{array}{c}\text { Total Jarak } \\
\text { (Meter) }\end{array}$ \\
\hline A & B & 2 & 6 & 12 \\
B & C & 1.5 & 10 & 15 \\
C & D & 1.5 & 26 & 39 \\
D & E & 1.5 & 16 & 24 \\
E & F & 1.5 & 16 & 24 \\
A & F & 4.5 & 4 & 18 \\
F & G & 1.5 & 25 & 37.5 \\
G & I & 3.5 & 30 & 105 \\
I & H & 2.5 & 30 & 75 \\
H & I & 2.5 & 30 & 75 \\
& & TOTAL & & $\mathbf{4 2 4 , 5}$
\end{tabular}

Jarak material handling untuk layout usulan dari raw material atau gudang bahan baku sampai storage atau gudang bahan jadi total jaraknya adalah 424.5 meter. Biaya pengangkutan per-meter adalah Rp.111.6/meter. Untuk mengetahui total biaya material handling dapat dihitung dengan mengalikan total jarak material handling dikalikan biaya pengankutan permeter. Hasil total biaya material handling untuk layout usulan adalah sebagai berikut :

Tabel 7. Total OMH Tata Letak Usulan

\begin{tabular}{ccccccc}
\hline From & To & $\begin{array}{c}\text { Material } \\
\text { Handling }\end{array}$ & $\begin{array}{c}\text { Jarak } \\
(\text { Meter })\end{array}$ & $\begin{array}{c}\text { OMH } \\
(\mathrm{Rp})\end{array}$ & Frekuensi & $\begin{array}{c}\text { Total OMH } \\
(\mathrm{Rp})\end{array}$ \\
\hline A & B & Manusia & 2 & 111.6 & 6 & 1339,2 \\
B & C & Manusia & 1.5 & 111.6 & 10 & 1674 \\
C & D & Manusia & 1.5 & 111.6 & 26 & 4352,4 \\
D & E & Manusia & 1.5 & 111.6 & 16 & 2678,4 \\
E & F & Manusia & 1.5 & 111.6 & 16 & 2678,4 \\
A & F & Manusia & 4.5 & 111.6 & 4 & 2008,8 \\
F & G & Manusia & 1.5 & 111.6 & 25 & 4185 \\
G & I & Manusia & 3.5 & 111.6 & 30 & 11718 \\
I & H & Manusia & 2.5 & 111.6 & 30 & 8370 \\
H & I & Manusia & 2.5 & 111.6 & 30 & 8370 \\
& \multicolumn{7}{c}{ TOTAL } & & & 47374,2 \\
\hline
\end{tabular}

Dari tabel diatas menunjukan bahwa total biaya yang keluar untuk Material Handling dalam satu hari Rp. 47.374,-

5. Analisis Perbandingan Usulan Perbaikan Tata Letak dengan Tata Letak Awal

Tahapan paling terakhir yaitu tahap analisis, setelah mengetahui jarak dan biaya perpindahan bahan/OMH dari setiap tata letak yang diusulkan. Tahap analisis ini merupakan tahapan membandingkan tata letak usulandengan tata letak awal UKM BM. Berikut ini merupakan tabel perbandingannya:

Tabel 8. Perbandingan Tata Letak Awal dan Usulan

\begin{tabular}{|c|c|c|}
\hline Tata Letak & Jarak Perpindahan & OMH \\
\hline Tata Letak Awal & 537.5 & Rp. 60.000,- \\
\hline Tata Letak Usulan & 424,5 & Rp. 47.374,- \\
\hline
\end{tabular}

Dari tabel diatas maka dapat dilihat total jarak dan biaya perpindahan material terendah adalah pada tata letak usulan dengan jarak perpindahan 424,5 Meter dan Biaya Perpindahan material sebesar Rp. 47.3744,dengan demikian didapatkan efisiensi biaya sebesar $12 \%$ perhari.

\section{SIMPULAN}

Berdasarkan hasil penelitian dan pengolahan data dari permasalahan yang dihadapi oleh UKM BM mengenai tata letak maka diperoleh kesimpulan sebagai berikut :

1. Perbaikan tata letak fasilitas produksi pada UKM BM dengan menggunakan metode From To Chart (FTC), diperoleh tata letak fasilitas produksi usulan yang sesuai dengan skala prioritas, sehingga menunjukan perubahan pada letak mesin yang lebih teratur sesuai dengan aliran proses produksi sehingga aliran material lebih baik dari sebelumnya.

2. Jarak material handling pada layout awal yaitu 537.5 meter/ produksi dengan ongkos material handling Rp. 60.000/ produksi. hasil rancangan perbaikan pada layout usulan menunjukan jarak material handling lebih pendek yaitu 424.5 meter/ produksi dengan ongkos material handling Rp. 47.374/ produksi.

3. Hasil perbaikan juga merubah tata letak fasilitas produksi yang tidak menghambat serta meningkatkan efesiensi perpindahan alur produksi tahu.

\section{REFERENCES}

[1] A. N. Ningtyas, M. Choiri, and W. Azlia, "Perancangan Ulang Tata Letak Fasilitas Produksi Dengan Metode Grafik Dan Craft Untuk Minimasi Ongkos Material Handling," J. Rekayasa dan Manaj. Sist. Ind., vol. 3, no. 3, pp. 495-504, 2015.

[2] E. G. Permata, "Perancang Ulang Tata Letak Pabrik dengan Membandingkan Metode Grafik dan Computerized Relative Allocation of Facilities Technique (Craft) untuk Meminimasi Ongkos Material Handling di PT. Perindustrian dan Perdagangan Bangkinang," J. Tek. Ind. J. Has. Penelit. dan Karya Ilm. 
dalam Bid. Tek. Ind., vol. 2, no. 2, p. 121, 2016, doi: 10.24014/jti.v2i2.5096.

[3] J. M. R. Joko Susetyo, Risma Adelia Simanjutak, "PENDEKATAN GROUP TECHNOLOGY DAN ALGORITMA BLOCPLAN UNTUK MEMINIMASI ONGKOS MATERIAL HANDLING Joko Susetyo , Risma Adelina Simanjuntak , João Magno Ramos," J. Teknol., vol. 3, no. Juni, pp. 75-83, 2010.

[4] F. Nurhidayat, "Usulan Perbaikan Tata Letak Fasilitas Lantai Produksi Dengan Metode Systematic Layout Planning (SLP) di PT DSS," Ikra-Ith Teknol., vol. 5, no. 80, p. 3, 2021

[5] Hari Purnomo, Perencanaan dan Perancangan Fasilitas. Jakarta: Graha Ilmu, 2004.

[6] I. N. Kamala, "Analisis Perancangan Tata Letak Gedung Pesantren dengan Menggunakan Pendekatan Systematic Layout Planning ( Studi Kasus: Pondok Pesantren Pagelaran 3 Cimeuhmal Subang ) Layout Design Analysis of Pesantren Building by Using Systematic Layout Planning Approach fasilitas, perancaan , desain dan susunan fasilitas, peralatan phisik dan manusia yang warna yang unik. Pesantren adalah lembaga pendidikan keagamaan yang mempunyai," pp. 1090-1096.

[7] Anwar, S. Bakhtiar, and R. Nanda, "Usulan perbaikan tata letak pabrik dengan menggunakan systematic layout planning (SLP) di CV. Arasco Bireuen," Malikussaleh Ind. Eng. J., vol. 4, no. 2, pp. 4-10, 2015, [Online]. Available:

https://www.journal.unimal.ac.id/miej/article/view/105. 